\title{
The Effect of Mechanical Activation and Lignin Impurities on the Hydrolysis-Dehydration of Cellulose in the Presence of Sibunit-4 Solid Acidic Carbon Catalysts
}

\author{
Nikolay V. Gromov*a,b, \\ Marina N. Denisova ${ }^{c}$, Tatiana B. Medvedeva ${ }^{a}$, \\ Dmitriy A. Yatsenko and Oxana P. Taran ${ }^{\mathrm{a}, \mathrm{d}, \mathrm{e}}$ \\ ${ }^{a}$ Boreskov Institute of Catalysis $S B R A S$, \\ 5 Lavrentiev, Novosibirsk, 630090, Russia \\ ${ }^{b}$ Novosibirsk State Technical University, \\ 20 Karl Marx, Novosibirsk, 630073, Russia \\ 'Institute for Problems of Chemical \\ and Energetic Technologies of the SB RAS \\ 1 Sotsialisticheskaya Str., Biysk, 659322, Russia \\ ${ }^{d}$ Institute of Chemistry and Chemical Technology $S B R A S$, \\ FRC "Krasnoyarsk Science Center SB RAS" \\ 50/24 Akademgorodok Str., Krasnoyarsk, 660036, Russia \\ eSiberian Federal University \\ 79 Svobodny, Krasnoyarsk, 660041, Russia
} Received 31.08.2019, received in revised form 06.09.2019, accepted 10.09.2019

In the presence of acidic catalysts based on the Sibunit-4 material the effects of mechanical activation and a lignin impurities on both the reactivity of cellulose and yields of products (monosaccharides and furfurals) being achieved during the hydrolysis of the polysaccharide isolated by hydrotropic cooking of miscanthus, wheat straw, and fruit shells of oats were studied. Activation was shown to significantly increase the reactivity of all substrates and the yields of the target products. Impurities of lignin led to decreasing product yields.

Keywords: hydrotropic cooking, miscanthus, oat fruit shells, wheat straw, Sibunit-4, mechanical activation, hydrolysis, lignin, glucose, 5-hydroxymethylfurfural, xylose, furfural.

Citation: Gromov N.V., Denisova M.N., Medvedeva T.B., Yatsenko D.A., Taran O.P. The effect of mechanical activation and lignin impurities on the hydrolysis-dehydration of cellulose in the presence of sibunit-4 solid acidic carbon catalysts, J. Sib. Fed. Univ. Chem., 2019, 12(3), 434-444. DOI: 10.17516/1998-2836-0140.

(c) Siberian Federal University. All rights reserved

* Corresponding author E-mail address: gromov@catalysis.ru 


\title{
Влияние механической активации и примесей лигнина \\ на гидролиз-дегидратацию целлюлозы \\ в присутствии твердых кислотных \\ углеродных катализаторов
}

на основе углеродного материала Сибунит-4

\author{
Н.В. Громов ${ }^{a, 0}$, М.Н. Денисова ${ }^{\text {, }}$ \\ Т.Б. Медведева ${ }^{a}$, Д.А. Яценко ${ }^{\text {a }}$ О.П. Таран ${ }^{\text {а,г,д }}$ \\ ${ }^{a}$ Институт катализа им. Г.К. Борескова СО РАН, \\ Россия, 630090, Новосибирск, пр. Академика Лаврентьева, 5 \\ ${ }^{\sigma}$ Новосибирский государственный технический университет, \\ Россия, 630073, Новосибирск, пр. Карла Маркса, 20 \\ ${ }^{8}$ Институт проблем химико-энергетических \\ технологий СО РАН, \\ Россия, 659322, Бийск, ул. Сочииалистическая, 1 \\ 'Институт химии и химической технологии СО РАН \\ ФИЦ «Красноярский научный изентр СО РАН» \\ Россия, 660036, Красноярск, Академгородок, 50/24 \\ ${ }^{\circ}$ Сибирский федеральньий университет \\ Россия, 660041, Красноярск, пр. Свободный, 79
}

Исследовано влияние механической активаџии и примесей лигнина на реакционную способность образиов целлюлозы, выделенныхметодомгидротропнойварки измискантуса, соломы пшениць и плодовых оболочек овса, в прочессе их гидролиза-дегидратации в присутствии твердых кислотных катализаторов, полученных сульфированием и окислением углеродного материала Сибунит-4. Показано, что активация существенно увеличивает реакционноспособность всех субстратов и выходы иелевых продуктов реакции (моносахаридов и фурфуролов). Наличие примесей лигнина приводит к уменьшению выходов продуктов в процессе деполимеризации целлюлозы.

Ключевые слова: целлюлоза, лигнин, гидротропная варка, мискантус, плодовые оболочки овса, солома пшеницы, механическая активаџия, Сибунит-4, гидролиз, глюкоза, 5-гидроксиметилфурфурол, ксилоза, фурфурол.

\section{Введение}

Истощение традиционных ископаемых источников сырья происходит постепенно, но неизбежно. Кроме того, их переработка создает большое количество экологических проблем. Все это делает перспективным поиск альтернативной сырьевой базы для получения ценных химических веществ. Перспективным альтернативным источником сырья представляется цел- 
люлоза. Она является основным компонентом возобновляемой растительной биомассы (содержание до 70 \%) и может быть выделена из отходов сельского хозяйства (шелухи овса, соломы пшеницы) и энергетических культур, растущих на бросовых землях (мискантус). Целлюлоза может быть использована для производства ряда ценных соединений, среди которых следует выделить глюкозу и 5-гидроксиметилфурфурол (5-ГМФ). Глюкоза - ценное, широко используемое промышленное соединение. 5-ГМФ может найти применение в топливной и химической отраслях, если будут разработаны эффективные и экологически безопасные технологии его производства [1].

Среди предложенных способов выделения целлюлозы из растительного сырья гидротропная делигнификация выступает перспективным методом $[2,3,4]$, поскольку по эффективности сопоставима с сульфатной варкой [5]. В качестве реагента при гидротропной варке используют бензоат натрия (пищевую добавку Е 211, разрешенную к употреблению в России и странах Европы). Для более полного удаления нецеллюлозных компонентов сырье после гидротропной варки подвергают многоступенчатой пероксидной отбелке. Однако даже после отбелки возможно сохранение в образцах целлюлозы других компонентов растительного сырья (гемицеллюлоз, лигнина, экстрактивных веществ, золы). В литературе имеются противоречивые данные, свидетельствующие и о влиянии остаточного лигнина на реакционноспособность целлюлозы и выходы продуктов гидролиза $[6,7,8]$, и об отсутствии такового $[9,10]$.

Серьезная проблема при разработке процессов деполимеризации целлюлозы - высокая степень ее кристалличности, которая может достигать 98 \% [11], что делает неизбежным применение жестких условий гидролиза. Разрушение кристаллической структуры является нетривиальной задачей. Предложен ряд способов активации целлюлозы, среди которых выделяется физический метод механической активации в планетарной мельнице [12, 13].

Гидролиз-дегидратация целлюлозы в глюкозу и 5-ГМФ на твердых кислотных катализаторах считается экологически безопасным «one-pot» процессом. Из всех известных твердых катализаторов (цезиевые соли ГПК, смолы, оксиды, цеолиты, углеродные материалы) именно углеродные наиболее перспективны $[14,15]$. Ранее нами показано, что в присутствии катализаторов на основе углеродного материала Сибунит-4 глюкоза и 5-ГМФ могут быть получены (с выходами до 46 и 21 \% соответственно) из химически чистой микрокристаллической активированной целлюлозы в чистой горячей воде [16].

В данной работе исследовано влияние механической активации и содержания остаточного лигнина на реакционную способность целлюлозы, полученной методом гидротропной варки из мискантуса, соломы пшеницы и плодовых оболочек овса, в процессе гидролиза-дегидратации в присутствии разработанных нами ранее твердых кислотных катализаторов на основе сульфированного или окисленного углеродного материала Сибунит-4 [16].

\section{Экспериментальная часть}

Реактивы и материалы: 5-ГМФ (98.0 \%, Acros), $\mathrm{H}_{2} \mathrm{SO}_{4}$ (96.0 \%, Acros), D-целлобиоза (99.5\%, Sigma-Aldrich), D-фруктоза (99.3\%, Sigma-Aldrich), D-манноза (99.5\%, Sigma-Aldrich), D-глюкоза (99.5 \%, Fisher Chemical), ксилоза (99.5\%, Sigma-Aldrich), фурфурол (99.0 \%, Acros); $\mathrm{NaOH}$ (99.3 \%, Panreac); искусственный воздух (20 об. \% О $\mathrm{O}_{2}$ в $\left.\mathrm{N}_{2}\right)$, аргон (99.998 \%, ОАО Сибтехгаз); деионизованная вода, очищенная на установке Milli-Q (Millipore). 
Образцы цุеллюлозы. В работе использованы три образца целлюлозы, выделенные методом одностадийной гидротропной варки из мискантуса, плодовых оболочек овса и соломы пшеницы, и один образец беленой целлюлозы, полученный из плодовых оболочек овса [3, 5]. Для сравнения взята химически чистая микрокристаллическая целлюлоза (фракция <0,10 мм, 3АО Вектон, Россия). Гидротропную варку исходной биомассы проводили в автоклаве при температуре $180{ }^{\circ} \mathrm{C}$ и постоянном перемешивании в течение 5 ч. В качестве варочного раствора использовали 35 \% водный раствор $\mathrm{C}_{6} \mathrm{H}_{5} \mathrm{COONa}$ (ТУ 64-6-395-86) [5]. Отбеливание целлюлозы проводили в $1 \%$ растворе $\mathrm{NaOH}$ и $\mathrm{H}_{2} \mathrm{O}_{2}$ при температуре $40{ }^{\circ} \mathrm{C}$ в течение 4 ч [5, 17].

Определение состава образцов цеелюлозы. Массовую долю целлюлозы, золы и гемицеллюлоз в образцах определяли по стандартизованным методикам ГОСТ [18-20]. Массовую долю лигнина или экстрактивных веществ определяли как соотношение массы лигнина или экстрактивных веществ, выделенных из образцов целлюлозы путем гидролиза минеральными кислотами или многократным экстрагированием хлористым метиленом, и массы исходного образца целлюлозы [21].

Механическую активацию образцов целлюлозы проводили в планетарной мельнице «Активатор-2S” (ЗАО Активатор, Россия) два раза по 10 минут (объем барабана 250 мл, масса целлюлозы 10 г, масса шаров 340 г, ускорение мелющих тел 76,8 g, диаметр шаров при первой активации 10 мм, при второй - 5 мм). Механическую активацию микрокристаллической целлюлозы проводили по методике, описанной в работе [22]. Степень кристалличности и размер частиц целлюлозы измеряли методами РФА (дифрактометр D8 Advanc, Bruker, Cu $K_{\alpha}(\lambda=1,5418$ Á), интервалом $0,05^{\circ}$, диапазон $2 \theta 10-40^{\circ}$ ) и оптической микроскопии (микроскоп Биомед-5, оснащенный цифровой фотокамерой, ООО Биомед-М) по методикам, представленным в работе [23].

Kamaлизаторы. В качестве катализаторов использовали мезопористый графитоподобный углеродный материал Сибунит-4 (Институт проблем переработки углеводородов, г. Омск), поверхность которого дополнительно модифицировали двумя способами: 1) сульфированием дымящейся $\mathrm{H}_{2} \mathrm{SO}_{4}$ при $\left.200{ }^{\circ} \mathrm{C}, 2\right)$ окислением влажной смесью газов $\left(20\right.$ об. \% $\mathrm{O}_{2}$ в $\left.\mathrm{N}_{2}\right)$ при $450{ }^{\circ} \mathrm{C}$ по методикам, описанным в работе [16].

Текстурные характеристики катализаторов исследовали путем низкотемпературной адсорбции азота (-204 ${ }^{\circ} \mathrm{C}$, прибор ASAP-2400, Micromeritics) [16]. Количество кислотных групп на поверхности катализаторов определяли методом кислотно-основного титрования с гидроксидом натрия [16]. Данные о текстурных характеристиках и количестве поверхностных кислотных групп приведены в табл. 1.

Таблица 1. Текстурные характеристики и содержание кислотных групп на поверхности катализаторов на основе углеродного материала Сибунит-4

Table 1. Texture parameters and amount of acid surface groups of Sibunit- 4 carbon catalysts

\begin{tabular}{|l|c|c|c|}
\hline \multicolumn{1}{|c|}{ Параметр } & Немодифицированный Сибунит-4 & C-S200 & C-O450 \\
\hline $\mathrm{S}_{\mathrm{BET}}, \mathrm{M}^{2} / \Gamma$ & 379 & 400 & 348 \\
\hline $\mathrm{V}_{\text {мезопор }, \mathrm{cm}^{3} / \Gamma}$ & 0.21 & 0.24 & 0.33 \\
\hline $\mathrm{C}_{\text {кисл.групп }, \text { ммоль } / \Gamma}$ & 0.042 & 0.40 & 0.28 \\
\hline $\mathrm{C}_{\text {кисл.групп }}, \mathrm{Mмоль} / \mathrm{M}^{2}$ & $1.0 \cdot 10^{-4}$ & $10.0 \cdot 10^{-4}$ & $8.0 \cdot 10^{-4}$ \\
\hline
\end{tabular}


Каталитические испытания образиов иеллюлозы проводили при температуре $180{ }^{\circ} \mathrm{C}$ в атмосфере аргона (1 MPa) в автоклаве высокого давления (Autoclave Engineers, США) при интенсивном перемешивании (1000 об/мин) по методике, описанной в работах $[16,23]$. Содержание субстрата и катализатора в растворе: 10 г/л. В ходе испытаний из автоклава через 1, 2, 3, 5 и 7 ч реакции отбирали пробы для анализа продуктов реакции методом ВЭЖХ на хроматографe Prominence LC-20 (Shimadzu), оборудованном рефрактометрическим и диодноматричным детекторами, на колонке Rezex RPM-Monosaccharide $\mathrm{Pb}^{2+}$ (Phenomenex, размер колонки 350·5.5 мм, температура колонки $70{ }^{\circ} \mathrm{C}$, элюент - деионизированная вода, скорость подачи элюента 0.6 мл/мин). Выходы продуктов гидролиза рассчитывали на их исходное содержание в образцах гидротропной целлюлозы по формуле [22]

$$
\mathrm{Y}=\frac{\mathrm{C}_{\text {продукт }} \mathrm{V}}{\mathrm{N}_{\mathrm{C}}\left(\mathrm{m}_{\text {Полисахарид }} / \mathrm{M}_{\text {Глюкан }}\right)} \cdot 100,
$$

где $\mathrm{Y}$ - выход продукта; $\mathrm{C}_{\text {продукт }}$ - концентрация продукта (моль/л); $\mathrm{V}$ - объем реакционной смеси (л); $\mathrm{N}_{\mathrm{C}}$ - коэффициент, учитывающий мольное соотношение углерода между продуктом и глюканом или остатком ксилозы (например, для глюкозы и ксилозы $\mathrm{N}_{\mathrm{C}}=1$ ); $\mathrm{m}_{\text {полисахарид }}$ - масса целлюлозы или ксилана (г); $\mathrm{M}_{\text {Глюкан }}-$ молярная масса глюкана в целлюлозе (162 г/моль) или остатка ксилозы в ксилане (132 г/моль).

\section{Результаты и их обсуждение}

В данной работе в качестве субстратов для гидролиза были использованы три образца гидротропной целлюлозы, полученных из травянистых культур: мискантуса, соломы пшеницы и плодовых оболочек овса (образцы Целл-М, Целл-СП, Целл-ПОО соответственно), и образец отбеленной целлюлозы, выделенной из оболочек овса (Б-Целл-ПОО). Для сравнения использовали химически чистую микрокристаллическую целлюлозу (Целл-ХЧ).

Проведено исследование состава образцов (табл. 2). Образец Целл-ХЧ является химически чистым веществом и не содержит нецеллюлозных компонентов. Все образцы гидротропной целлюлозы содержат примеси лигнина, гемицеллюлоз, золы и экстрактивных веществ. Содержание целлюлозы в образцах составило 76.0-83.6 \% и увеличивалось в ряду: Целл-ПОО < Целл-СП < Целл-М <Б-Целл-ПОО. Содержание лигнина во всех образцах находилось в диапазоне 6.6-7.8 \%, гемицеллюлоз - 6.1-13.8 \%, золы - 2.6-3.2 \%, экстрактивных веществ менее $1 \%$ (табл. 2). Дополнительная отбелка целлюлозы (Б-Целл-ПОО) позволила сократить содержание примесей лигнина, гемицеллюлоз и экстрактивных веществ в $~ 2.7,6.5$ и 2 раза соответственно (табл. 2). Следует подчеркнуть, что состав примесей в образцах связан с составом исходного сырья [5].

Хорошо известно, что высокая степень кристалличности и большой размер частиц целлюлозы крайне негативно влияют на её реакционноспособность, тогда как предварительная активация позволяет сократить время реакции каталитического гидролиза целлюлозного сырья и снизить температуру проведения процесса [13, 22]. В данной работе применялся метод механического размола в планетарной шаровой мельнице. Этот метод более перспективен по сравнению с такими, как химическая обработка, термическая обработка, микроволновое об- 
лучение, $\gamma$-облучение, СВЧ-обработка и ультразвуковая обработка, благодаря высокой экологической безопасности [13].

Исследование размера частиц образцов целлюлозы проводили методом оптической микроскопии. Исходные образцы гидротропной целлюлозы имеют волокнистую структуру с длиной волокон более 200 мкм (табл. 2, рис. 1). Размер исходной микрокристаллической целлюлозы, по данным микроскопического исследования, составил $114 \pm 35$ мкм (табл. 2, см. рис. в [23]). После механической активации для всех образцов гидротропной целлюлозы (Целл-М-А, ЦеллСП-А, Целл-ПОО-А и Б-Целл-ПОО-А) наблюдается изменение формы частиц с длинных волокон на небольшие сферические структуры. Размер частиц существенно уменьшился и составил $17.4 \pm 9.4,6.9 \pm 2.8,10.1 \pm 3.8$ и 23,3 \pm 10.5 мкм для образцов Целл-М-А, Целл-СП-А, Целл-ПОО-А и Б-Целл-ПОО-А соответственно (табл. 2, рис. 1). Размер частиц микрокристаллической целлю-

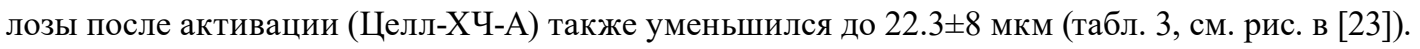

Таблица 2. Состав, средний размер частиц $(<\mathrm{d}>)$ и степень кристалличности (СК) образцов целлюлозы. * - до и после активации

Table 2. Composition, average particle size $(<\mathrm{d}>)$ and crystalline index $(\mathrm{CI})$ of cellulose samples. $*$ - before and after activation

\begin{tabular}{|l|c|c|c|c|c|c|c|c|c|}
\hline \multirow{2}{*}{\multicolumn{1}{|c|}{ Шифр }} & \multicolumn{5}{|c|}{ Массовая доля, \% } & \multicolumn{2}{c|}{$<\mathrm{d}>$, мкм } & \multicolumn{2}{c|}{ СК, \% } \\
\cline { 1 - 12 } & Целл & Лигнин & Золы & Гемицелл & Экстрак. в-ва & до* & после* & до* & после* \\
\hline Целл-М & 83.6 & 6.6 & 2.8 & 6.1 & 0.8 & $>200$ & $17.4 \pm 9.4$ & $90-100$ & $<10$ \\
\hline Целл-СП & 79.1 & 7.8 & 2.6 & 9.7 & 0.7 & $>200$ & $6.9 \pm 2.8$ & $60-80$ & $<10$ \\
\hline Целл-ПОО & 76.0 & 6.7 & 3.2 & 13.8 & 0.2 & $>200$ & $10.1 \pm 3.8$ & $80-90$ & $<10$ \\
\hline Б-Целл-ПОО & 92.7 & 2.5 & 2.5 & 2.1 & 0.1 & $>200$ & $23.3 \pm 10.5$ & $70-80$ & $<10$ \\
\hline Целл-ХЧ & 100.0 & 0 & 0 & 0 & 0 & $114 \pm 35$ & $22.3 \pm 8$ & $90-100$ & $35-40$ \\
\hline
\end{tabular}
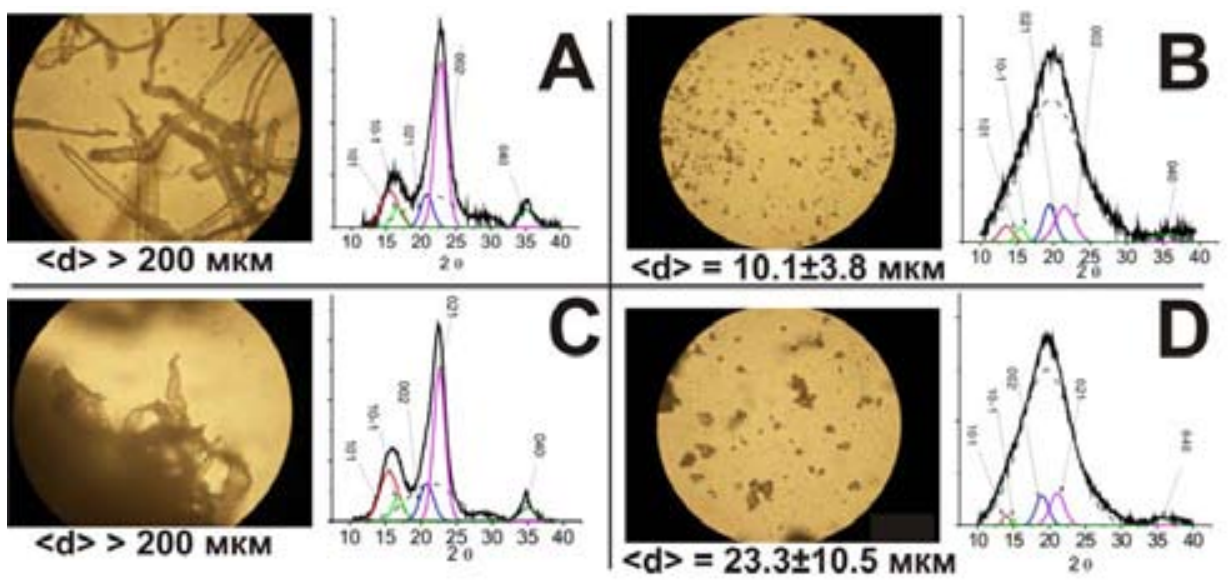

Рис. 1. Микрофотографии и рентгенограммы целлюлозы на примере образцов Целл-ПОО (А, В) и Б-ЦеллПОО $(\mathrm{C}, \mathrm{D})$ до $(\mathrm{A}, \mathrm{C})$ и после активации $(\mathrm{B}, \mathrm{D}) .<\mathrm{d}>-$ средний размер частиц целлюлозы

Fig. 1. Optical micrographs and X-ray patterns of Cell-POO (A, B) and B-Cell-POO (C, D) samples as an example of cellulose before $(A, C)$ and after $(B, D)$ activation. $<\mathrm{d}>-$ average cellulose particle size 
Проведено исследование степени кристалличности образцов методом РФА. Степень кристалличности (СК) была оценена по методике, адаптированной из работы [24]. До активации образцы целлюлозы характеризуются очень высокой степенью кристалличности. Для образцов Целл-М и Целл-ХЧ СК составила 90-100 \%, целлюлозы из соломы пшеницы - 60-80 \%, целлюлозы из плодовых оболочек овса - 80-90 \%, беленой целлюлозы из плодовых оболочек овса $-70-80$ \% (табл. 2, рис. 1). На рентгенограммах механически активированных образцов наблюдалось размывание и уменьшение интенсивности пиков 110, 021, 002 и 040, характерных для кристаллической структуры целлюлозы, и появление аморфного гало (рис. 1). Степень кристалличности активированного образца химически чистой микрокристаллической целлюлозы составила 35-40 \% (табл. 2, см. рис. в [23]). Изменение кристаллической структуры всех образцов гидротропной целлюлозы оказалось очень значительным (рис. 1). Степень кристалличности - менее $10 \%$ (табл. 2, рис. 1).

Для исследования влияния степени кристалличности, а также содержания лигнина в образцах целлюлозы на процесс каталитического гидролиза полисахаридного сырья были проведены сравнительные эксперименты в присутствии твердых кислотных углеродных катализаторов C-O450 и C-S200. Катализаторы представляют собой углеродный материал Сибунит-4, на поверхности которого химически закреплены кислотные кислородсодержащие (лактонные, карбонильные, фенольные, карбоксильные) и сульфогруппы (см. экспериментальную часть и табл. 1). Общее количество кислотных групп, определенное титрованием с $\mathrm{NaOH}$, на поверхности катализаторов C-O450 и C-S200 составило 0.28 и 0.40 ммоль/г. Испытания проводили в автоклаве при температуре $180{ }^{\circ} \mathrm{C}$ в атмосфере аргона (1 МПа) и при интенсивном перемешивании (1000 об/мин) [16].

Анализ проб реакционных смесей методом ВЭЖХ показал при гидролизе и дальнейших превращениях химически чистой целлюлозы образование: целлобиозы, глюкозы, маннозы, фруктозы, 5-ГМФ, левулиновой и муравьиной кислот. Однако в образцах целлюлозы, полученных из мискантуса и отходов сельскохозяйственных культур, присутствуют гемицеллюлозы (2.1-13.8 \%), которые представлены преимущественно ксиланом [5]. Гидролиз ксилана приводит к ксилозе, из которой образуется фурфурол [5]. Следует отметить, что фурфурол может также образовываться при дегидратации фруктозы, однако ранее нами было показано, что при гидролизе целлюлозы выходы фурфурола крайне малы и вкладом данной реакции можно пренебречь [16].

Основными продуктами гидролиза образцов целлюлозы, полученных гидротропной варкой из сельскохозяйственных культур, являлись соответствующие мономеры - глюкоза и ксилоза, а также продукты их дегидратации - 5-ГМФ и фурфурол (табл. 3). Выходы остальных продуктов гидролиза были незначительными. Результаты исследований показывают, что гемицеллюлозы значительно легче подвергаются гидролизу, чем целлюлоза. Так, в присутствии катализатора C-S200 для неактивированных образцов суммарный выход (Y Гемиц) продуктов гидролиза гемицеллюлоз варьировался от 25 до 48 \%, тогда как общие выходы продуктов ги-

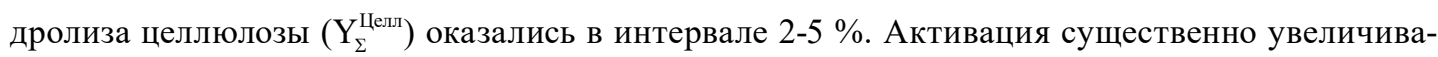
ет реакционноспособность субстратов и выходы целевых продуктов реакции (рост значения

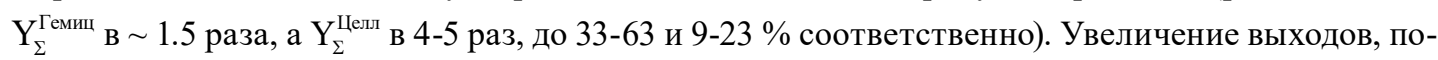
видимому, обусловлено разрушением как кристаллической структуры самой целлюлозы, так 
и химических связей между целлюлозными и гемицеллюлозными полисахаридами [13]. Сравнение выходов продуктов гидролиза собственно целлюлозы показывает, что из Целл-СП-А можно достичь больших выходов глюкозы и 5-ГМФ по сравнению с образцами Целл-М-А и Целл-ПОО-А, очевидно, благодаря меньшим размерам частиц и степени кристалличности образца (табл. 2 и 3 ).

Наши исследования подтвердили негативное влияние лигнина на реакционоспособность целлюлозы и выходы продуктов реакции. Так, в присутствии катализатора C-S200 суммарные выходы продуктов, полученных из образца Б-Целл-ПОО, в 1.5-1.8 раза выше по сравнению с неотбеленным образцом Целл-ПОО (как при наличии, так и в отсутствие стадии активации), но в $~ 1.5$ раза меньше, чем у Целл-ХЧ-А, не содержащего примесей лигнина (табл. 3). Снижение выходов продуктов гидролиза лигниносодержащих образцов может быть связано как с уменьшением реакционоспособности самой целлюлозы из-за химического связывания полисахарида с остаточным лигнином, так и с негативным влиянием лигнина на активность катализаторов.

Вместе с тем, сравнение выходов продуктов, полученных в присутствии катализаторов $\mathrm{C}-\mathrm{S} 200$ и C-O450, позволяет сделать предположение о различной силе влияния примесей лигнина на активность поверхностных кислотных групп разной химической природы в составе углеродных катализаторов. Так, более высокие выходы продуктов гидролиза-дегидратации

Таблица 3. Максимальные выходы основных продуктов гидролиза образцов целлюлозы в присутствии катализаторов C-S200 и C-O450

Table 3. Highest yields of cellulose hydrolysis products over C-S200 and C-O450 catalysts

\begin{tabular}{|c|c|c|c|c|c|c|c|c|}
\hline \multirow{3}{*}{$\begin{array}{c}\text { Образец } \\
\text { целлюлозы }\end{array}$} & \multicolumn{8}{|c|}{ Выходы основных продуктов } \\
\hline & \multirow{2}{*}{$\mathrm{Y}_{\Sigma}^{\text {Гемиц }}, \%$} & \multirow{2}{*}{$\mathrm{Y}_{\Sigma}^{\text {Целл }}, \%$} & \multirow{2}{*}{ Глюкоза } & \multirow{2}{*}{ 5-ГМФ } & \multirow{2}{*}{ Ксилоза } & \multirow{2}{*}{ Фурфурол } & \multicolumn{2}{|c|}{ Ксилоза* } \\
\hline & & & & & & & Y \% & $\mathrm{t}, \mathrm{Y}$ \\
\hline \multicolumn{9}{|c|}{ Катализатор C-S200 } \\
\hline Целл-М & 29 & 2 & 1 & 1 & 2 & 27 & 3.8 & 5 \\
\hline Целл-М-А & 39 & 9 & 5 & 2 & 3 & 36 & 16 & 2 \\
\hline Целл-СП & 25 & 4 & 1 & $<1$ & 5 & 20 & 6 & 3 \\
\hline Целл-СП-А & 33 & 18 & 9 & 4 & 3 & 30 & 27 & 1 \\
\hline Целл-ПОО & 26 & 3 & 1 & 1 & 6 & 19 & 12 & 2 \\
\hline Целл-ПОО-А & 34 & 15 & 8 & 5 & 1 & 32 & 32 & 1 \\
\hline Б-Целл-ПОО & 48 & 5 & 2 & 2 & 15 & 33 & 35 & 1 \\
\hline Б-Целл-ПОО-А & 63 & 23 & 11 & 7 & $<1$ & 62 & 42 & 1 \\
\hline Целл-ХЧ-А & - & 39 & 21 & 12 & - & 4 & - & - \\
\hline \multicolumn{9}{|c|}{ Катализатор C-O450 } \\
\hline Целл-М-А & 52 & 10 & 4 & 3 & 9 & 43 & 21 & 3 \\
\hline Целл-СП-А & 43 & 18 & 8 & 6 & 3 & 40 & 26 & 3 \\
\hline Целл-ПОО-А & 46 & 20 & 9 & 6 & 4 & 42 & 34 & 2 \\
\hline Б-Целл-ПОО-А & 65 & 24 & 13 & 8 & 0 & 65 & 36 & 1 \\
\hline Целл-ХЧ-А & - & 34 & 19 & 12 & - & 2 & - & - \\
\hline
\end{tabular}


чистой микрокристаллической целлюлозы наблюдаются в присутствии катализатора C-S200, на поверхности которого присутствуют как сульфо-, так и кислородсодержащие группы. В присутствии катализатора $\mathrm{C}-\mathrm{O} 450$, на поверхности которого находятся только кислородсодержащие активные центры, выходы продуктов ниже на 5 \%. Подобные различия в выходах продуктов деполимеризации целлюлозы в присутствии аналогичных катализаторов мы наблюдали ранее [16]. Однако при гидролизе-дегидратации всех лигниносодержащих образцов целлюлозы, используемых в данной работе, выходы глюкозы и 5-ГМФ оказались несколько выше (на 1-5 \%) в присутствии катализатора С-O450, несмотря на меньшее суммарное содержание поверхностных кислотных групп в этом катализаторе по сравнению с каталитической системой C-S200. Значения суммарных выходов продуктов гидролиза-дегидратации примесных

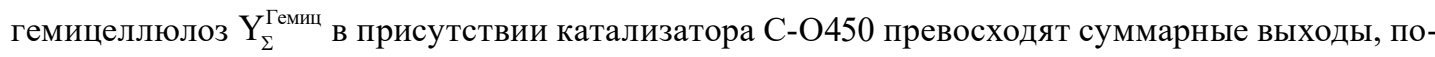
лученные в присутствии C-S200, на 10-13 \%. Однако для образца беленой целлюлозы Б-ЦеллПОО-А с наименьшим содержанием лигнина разница в активности катализаторов значительно менее выражена по сравнению с образцами Целл-М, Целл-СП-А и Целл-ПОО-А. Достигнуты $\mathrm{Y}_{\Sigma}^{\text {Гемиц }}$, равные 65 и 63 \% в присутствии C-O450 и C-S200 соответственно. Таким образом, полученные данные могут свидетельствовать о более сильной дезактивации поверхностных сульфогрупп по сравнению с кислородсодержащими активными центрами. Тем не менее необходимо проведение дополнительных исследований, направленных на уточнение механизма дезактивирующего воздействия лигнина.

\section{Заключение}

В присутствии сульфированных и окисленных углеродных катализаторов на основе Сибунита проведено исследование влияния механической активации и примесей лигнина на реакционноспособность микрокристаллической целлюлозы, выделенной методом гидротропной варки из мискантуса, соломы пшеницы и плодовых оболочек овса, в процессе одностадийного гидролиза целлюлозы в гидротермальной среде. Обнаружено, что наиболее реакционноспособным оказался образец целлюлозы, выделенной из соломы пшеницы, благодаря меньшим размерам частиц и степени кристалличности. Активация существенно увеличивает реакционную способность всех субстратов и выходы целевых продуктов реакции (в $\sim 1.5$ и 4-5 раз при гидролизе остаточных гемицеллюлоз и целлюлозы соответственно). В целом при гидролизе механически активированных образцов целлюлозы, выделенной из растительного сырья, суммарные выходы продуктов гидролиза гемицеллюлозного и целлюлозного компонентов достигают 33-63 и 9-23 \% соответственно. Продемонстрировано негативное влияние лигнина на процесс деполимеризации целлюлозы, которое выражается в уменьшении суммарных выходов продуктов реакции и может быть вызвано как химическим связыванием между лигнином и целлюлозой, так и дезактивацией катализатора. Сделано предположение о различной силе влияния лигнина на активность поверхностных сульфо- и карбоксильных кислотных групп. Обнаружено, что сульфогруппы подвергаются более сильной дезактивации под воздействием лигнина по сравнению с кислородсодержащими активными центрами. Необходимо проведение дополнительных исследований, направленных на установление механизма дезактивирующего действия лигнина на твердые кислотные катализаторы в процессе гидролиза целлюлозы. 


\section{Благодарности}

Исследование выполнено в рамках государственного задания Института катализа им. Г.К. Борескова СО РАН (проект АААА-А17-117041710075-0).

\section{Список литературы}

1. van Putten R.-J., van der Waa, J. C., de Jong E., et al. Hydroxymethylfurfural, A Versatile Platform Chemical Made from Renewable Resources. Chemical Reviews. 2013. Vol. 113. P. 1499-1597.

2. Gabov K., Fardim P., Gomes F. Hydrotropic fractionation of birch wood into cellulose and lignin: A new step towards green biorefinery. Bioresouces. 2013. Vol. 8. P. 3518-3531.

3. Denisova M.N., Budaeva V.V., Pavlov I.N. Pulps isolated from Miscanthus, oat hulls, and intermediate flax straw with sodium benzoate. Korean Journal of Chemical Engineering. 2015. Vol. 32(2). P. 202-205.

4. Ansari K.B., Gaikar V.G. Green hydrotropic extraction technology for delignification of sugar cane bagasse by using alkybenzene sulfonates as hydrotropes. Chemical Engineering Science. 2014. Vol. 115. P. 157-166.

5. Денисова М.Н. Гидротропная делигнификация недревесного сырья : дис. ... канд. хим. наук: 05.21.03. Институт проблем химико-энергетических технологий СО РАН. Бийск, 2014. 137 с. [Denisova M. N. Hydrotropic kraft process of non wood raw materials PhD Thesis: 05.21.03. Institute for Problems of Chemical and Energetic Technologies of the SB RAS. Biysk, 2014. 137 p. (In Russ.)]

6. Кузнецов Б.Н., Чесноков Н.В., Гарынцев Н.В., Яценков О.В. Интегрированная каталитическая переработка древесины осины в жидкие и твердые биотоплива. Журнал Сибирского федерального университета. Химия. 2013. Т. 6. С. 286-298 [Kuznetsov B.N., Chesnokov N.V., Garyntsev N.V., Yatsenkov O.V. Integrated catalytic processing of aspen wood to liquid and solid biofuels. J. Siberian Federal University. Chemistry 2013. Vol. 6. P. 286-298 (In Russ.)]

7. Jordan D.B., Bowman M.J., Braker J.D., et. al.. Plant cell walls to ethanol. Journal of Biochemistry. 2012. Vol. 442. P. 241-252.

8. Saha B.C. Hemicellulosic bioconversion. Journal of Industrial, Microbial Biotechnology. 2003. Vol. 30. P. 279-291.

9. Skiba E.A., Budaeva V.V., Baibakova O. V., et. al. Enzymatic hydrolysis of lignocellulosic materials in aqueous media and the subsequent microbiological synthesis of bioethanol. Catalysis in Industry. 2016. Vol. 8. P. 168-175.

10. Makarova E.I., Budaeva V.V., Skiba E.A., et. al. Enzymatic hydrolysis of celluloses obtained via the hydrothermal processing of Miscanthus and oat hulls. Catalysis in Industry. 2014. Vol. 8. P. 67-71.

11. Колвин Д. Р. Целлюлоза и ее производные. Т. 2. Под ред. Н. Байклза и Л. Сегала. М.: Мир, 1974. 249 с. [Kolvin D. P. Cellulose and it's derivatieves.2 Vol. 2. Under Ed. N. Baiklz and L. Segal. Moscow: Mir, 1974. 249 p. (In Russ.)].

12. Singh R., Shukla A., Tiwari S., et al. A review on delignification of lignocellulosic biomass for enhancement of ethanol production potential. Renewable Sustainable Energy Reviews. 2014. Vol. 32. P. 713-728.

13. Gromov N.V., Taran O.P., Sorokina K.N., et. al. New methods for the one-pot processing of polysaccharide components (cellulose and hemicelluloses) of lignocellulose biomass into valuable products. Part 1: Methods for biomass activation. Catalysis in Industry. 2016. Vol. 8. P. 176-186.

$$
-443-
$$


14. Serrano-Ruiz, J. C., Luque, R., Sepulveda-Escribano, A. Transformations of biomass-derived platform molecules: from high added-value chemicals to fuelsvia aqueous-phase processing. Chemical Society Reviews. 2011. Vol. 40(11). P. 5266-5281.

15. Hu, L., Lin, L., Wu, Z., et al. Chemocatalytic hydrolysis of cellulose into glucose over solid acid catalysts. Appied. Cataysis. B: Environmental. 2015. Vol. 174-175. P. 225-243.

16. Gromov N.V., Medvedeva T.B,Taran O.P., et. al. Hydrothermal Solubilization-HydrolysisDehydration of Cellulose to Glucose and 5-Hydroxymethylfurfural Over Solid Acid Carbon Catalysts, Topics in Catalysis. 2018. Vol. 61. P. 1912-1927.

17. Пен Р.3. Технология древесной массы. Красноярск: Изд-во СибГТУ, 1997. 220 с. [Pen R.Z Technology of wood-pulp. Tutorial for universities. Krasnoyarsk: SibSTU Publisher, 1997. 220 p. (In Russ.)]

18. ГОСТ 6840-78. Целлюлоза. Метод определения содержания альфа-целлюлозы. М.: Изд-во стандартов, 1978. 5 с. [GOST 6840-78. Cellulose. Method of alfa-cellulose analysis. Moscow: Izdatel'stvo standartov, 1978. 5 p. (In Russ.)]

19. ГОСТ 18461-93. Целлюлоза. Метод определения содержания золы. М.: Изд-во стандартов, 1993. 6 с. [GOST 18461-93. Cellulose. Method of ashes analysis. Moscow: Izdatel'stvo standartov, 1993. 6 p. (In Russ.)]

20. ГОСТ 10820-75. Целлюлоза. Метод определения массовой доли пентозанов. М.: Изд-во стандартов, 1975. 6 c. [GOST 10820-75. Cellulose. Method of pentosan analysis. Moscow: Izdatel'stvo standartov, 1975. 6 p. (In Russ.)]

21. Оболенская А. В., Ельницкая 3. П., Леонович А. А. Лабораторные работы по химии древесины и иеллюлозы. М.: Экология, 1991. 320 c. [Obolenskaya A. B., El'nitskaya Z.P., Leonovich A.A. Laboratory works in chemistry of wood and cellulose. Tutorial for universities. Moscow: Ekologiya, 1991. 320 p. (In Russ.)]

22. Gromov N.V, Taran O.P, Delidovich I.V, et. al. Hydrolytic oxidation of cellulose to formic acid in the presence of Mo-V-P heteropoly acid catalysts, Catal Today. 2016. Vol. 278. P 74-81.

23. Gromov N.V., Taran O.P., Semeykina V.S., et. al. Solid acidic $\mathrm{NbO}_{\mathrm{x}} / \mathrm{ZrO}_{2}$ catalysts for transformation of cellulose to glucose and 5-hydroxymethylfurfural in pure hot water, Catal Lett., 147 (2017). P. 1485-1495.

24. Park S., Baker J., Himmel M., Parilla P., Johnson D. Cellulose crystallinity index: measurement techniques and their impact on interpreiting cellulose performance, Biotechnol. for fuels. 2010. Vol. 3. P. 10. 